\title{
RED CROSS PHILATELY
}

On the occasion of its centennial anniversary and the international meetings held at The Hague in September 1967, the Netherlands Red Cross organized an exhibition of photographs and material giving a vivid portrayal of its varied activities. An interesting feature was the display of Red Cross postage stamps.

The collection of Mr. C. D. Ricardo, the well-known Netherlands specialist of Red Cross philately, was one of the fascinating aspects of the Red Cross exhibition at Pulchri Studio, Lange Voorhout 15. Mr. Ricardo, who died in 1966, bequeathed to The Netherlands Red Cross his 85 albums containing one of the finest collections in the world.

The eighteen frames on view, containing some of the collection's rarest items, gave a striking insight into Red Cross philately: the mails in the service of the humanitarian ideal, in the most varied and often the most difficult circumstances.

Special mention should be made of the "Red Cross classics", some hundred envelopes bearing seals and postmarks of 1870 and the following years. These envelopes represented the first steps of the International Committee of Geneva, the International Agency of Bâle and the different committees established in several Swiss towns for the relief of the wounded of the Franco-Prussian war of 1870 .

Other items of great interest testified to the intensive activity of the committees of the French Society of Relief for Wounded Soldiers, to the work of ambulances giving care to the victims of the Franco-Prussian war of 1870-1871, the communication of news to families or the search for relatives.

One extremely rare envelope sent by balloon during the siege of Paris bore the cancellation "Société de secours aux blessés militaires de Paris 20.10.1870" (Society for the Relief of Wounded Soldiers, Paris 20.10.1870). 
These letters are indeed pages of the history of the very origins of the Red Cross in its traditional relief role.

Another fine exhibit was a letter-card bearing the Red Cross emblems and dated 13 August 1870 with the heading of the St-Louis Committee (Upper Rhine, France) of the International Society of Relief for Wounded Soldiers, with the following text: "This Committee puts itself at your entire disposal for the letters you may have to send to Germany or receive from that country ".

The other frames offered a veritable world tour through envelopes, cards, cancellations, postage stamps and seals, most of which were rarities.

There was a magnificent series of "visiting envelopes" of the Russian Red Cross for the period 1878-1903, an exceptional set of precursors of the " charity" stamps of the Ottoman Red Crescent between 1910 and 1916, Red Cross stamps and seals on letters through the years, right up to the issues in tribute to the Red Cross Centenary, celebrated the world over in 1963.

\section{League of Red Cross Societies Report}

The League's Annual Report for 1966 covers its activities under the following headings: Development Programme; Relief, Health and Social Service; Nursing; Youth; Public Relations; and International Relations. It is concluded by financial statements.

In his introduction, Mr. H. Beer, Secretary-General, draws attention to some major problems: "With the growing universality of the Red Cross, the League is faced with constantly increasing responsibilities. Since the XXth International Conference of the Red Cross, (Vienna, October 1965), the League's activities have vastly developed, while the economic and technical difficulties with which it has had to contend during the past months have shown no signs of diminishing.

Two essential and closely interdependent activities have headed the list of priorities, both calling for the utmost degree of attention 